\title{
Fun and creative learning using discovery learning in Islamic economics: A Technological approach
}

\author{
V.A. Qurrata*, S. Merlinda \& R.D.L. Puteri \\ Universitas Negeri Malang, Malang, Indonesia
}

\begin{abstract}
The purpose of the present study was to investigate the implementation of discovery learning on Islamic economics. This study used classroom action research. The subject was 25 undergraduate students who were enrolled Islamic economics majors, and data was collected using a questionnaire, observation, tasks, and documentation. The data was analyzed descriptively. The results showed that the participants never used discovery learning for the class activity before. This new experience had a positive impact on the participants' perception on Islamic economics learning. Discovery learning was found to be more practical compared to the traditional method. Moreover, this study found that the participants were attracted to learning the idea in discovery learning through direct interaction with society.
\end{abstract}

Keywords: discovery learning, Islamic economics, classroom action research

\section{INTRODUCTION}

Learning models are varied and have characteristics. One of these models is discovery learning, which is a model used to solve problems by students independently under teacher supervision (Indriyanti \& Prasetyo 2018). Furthermore, discovery learning is a cognitive learning method that requires teachers to be more creative in creating situations that can make students learn to discover their knowledge actively. Through this method, students will try to learn and find conclusions from a material. Through this method, it is hoped that students will not only listen passively to the lecturers but will be more active in seeking new knowledge.

The learning process through a discovery learning model using a scientific approach can improve students' critical thinking skills and learning outcomes (Balım 2009). Learning outcomes using the discovery learning method could increase students' average scores in mathematics learning outcomes compared to conventional methods (Sari \& Sukartiningsih 2014). The results of implementing the discovery learning model were also stated by Joyce and Weil (2009), using this method, students can increase activeness and participation in learning activities. This condition is reflected in the courage of students to express, argue, accept other people's opinions and work together in groups. The dominance of specific student groups is no longer visible, and various activities are carried out by each student with full responsibility such as in the presentation of the material. Additionally, learning through this method is also supported by the improvement of every aspect of assessment: both in aspects of the process and in learning outcomes (with the achievement of minimum completeness criteria).

Based on the description above, the learning model that is considered capable of empowering social attitudes, cognitive knowledge and science process skills is the discovery learning model. This learning model should be considered and implemented in learning Islamic Economics. Islam distinguishes between economics and the economic system. In the general definition, the system is a complex whole, namely an arrangement of things or parts that are interconnected, whereas

\footnotetext{
*Corresponding author: vika.annisa.fe@um.ac.id
} 
science is the knowledge that is formulated systematically. The system can be defined as any rule born from a worldview or a specific creed that functions to solve and overcome the problems of human life, one that explains how to solve, maintains and develop these solutions. At the theoretical and conceptual level, teaching Islamic Economics is limited to curriculum sources and materials. The books used in learning activities do not effectively encourage students to find concepts and express their ideas (Amalia \& Al Arif 2013). The Islamic Economics material is challenging to understand and does not encourage students to carry out science-based learning activities (Febrianto \& Wahyuningsari 2017).

Islamic economics is a new science that is still common to students. Islamic economics has many foreign terms in Arabic, which are difficult for students to memorize. Furthermore, the concept in Islamic Economics is still new, especially for students who are not too steeped in religious knowledge. Therefore, the discovery learning method is important to be used in learning Islamic Economics in a fun way and makes it easier for students to understand this science. This research wants to find out how effective this method can be in teaching students to understand Islamic Economics.

\section{METHODS}

The design of the implementation of learning innovation in the discovery learning model was carried out on subjects whose substance contains case study elements that require a solution based on existing theory and require a legal basis. Wenning (2011) stated that the steps of discovery learning are observation, manipulation, generalization, verification, and application. Students face phenomena that interest them in the module's observation stage and respond to them. This is in agreement with Lavine (2005), which stated that clinical cases presented in guided discovery learning function to focus on real problems and increase relevance and motivation to master science basics.

This module's outstanding characteristic is that in every activity, it places great emphasis on group cooperation in discovering concepts, not on individuals. Modules are the best way for students to actively study together with friends. At the same time, the lecturer checks intensively and aids students who have difficulty studying modules individually (Swaak et al. 2004). The following is a picture of the discovery learning development design implemented in the Islamic Economics course.

Based on the image above, there are 4 phases in discovery learning specifications. First, the material is discussed and the groups divide. Second, discussions are conducted by students in one group. This discussion aims to finalize the concept. Then, students also conduct interviews with the community and experts according to each group theme. The results of the interview are then used in making the video (vlog). Third, the video packaged in the form of a vlog is uploaded to the IG Department of Development Economics and UM E-learning. Next, the video is presented and discussed with other groups. Then, the teacher gives a case to be solved by the group concerned. Fourth, students compile papers based on the material that has been discussed and the explanations and conclusions of the speakers. The teacher provides a review and additions (if needed) to the modules prepared by students from the papers prepared. Next, the lecturer arranges modules on each related theme, then uploads them to the e-learning system. Fifth, in addition to the value, the lecturer will task the student with whether they can develop concepts and calculations according to the software theme. Sixth, validation, which is carried out by material experts in each field.

After the e-module output is compiled, there is the need for further validation. Validation is carried out to test the discovery learning based Islamic economics module's feasibility, so experts are needed to do this. Validation is a process or validation of the module's conformity to the needs (Kamel 2014). Furthermore, Daryanto (2013) states that validation can be done by asking for help from experts who master the studied competencies. Thus, the requirements for a validator are that they must hold bachelors or masters degree titles in their field as needed. There are two validators in the assessment of this module, namely material experts in: (i) financing, (ii) zakat, (iii) waqf, 


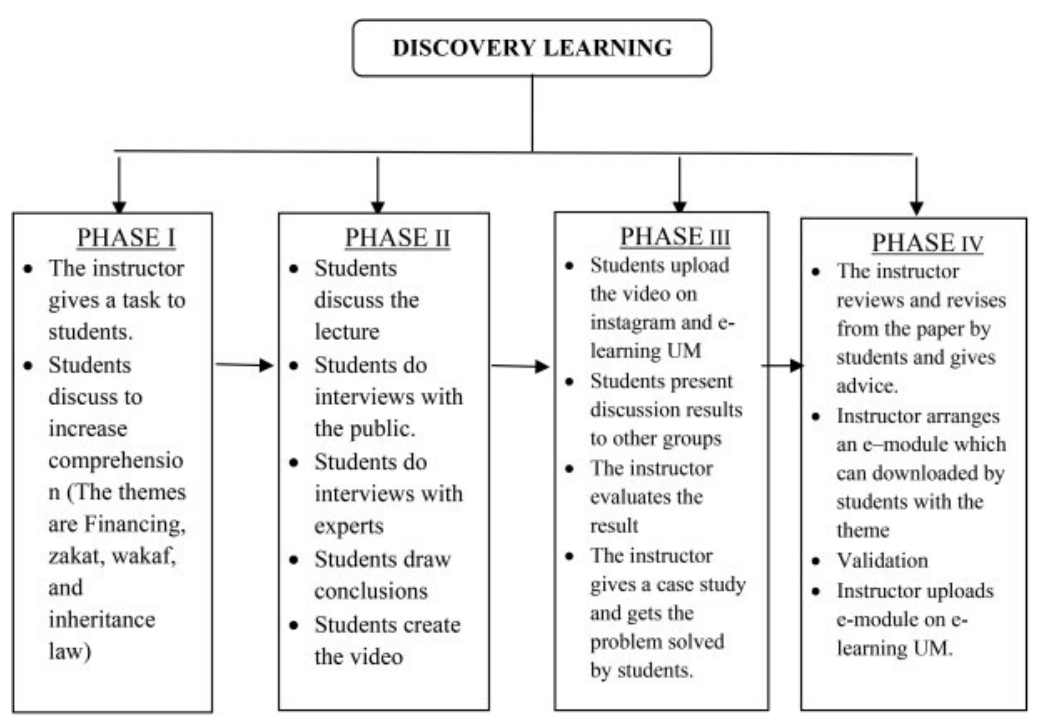

Figure 1. The phase of discovery learning's development plan.

and (iv) inheritance. Islamic Economics lecturers carry out the material validator. The purpose of material validation is to determine the feasibility and adequacy of the material presented. In preparing the material, it must pay attention to the depth and breadth of material coverage. The material's breadth describes how much material is included, while the depth of the material concerns the details of the concepts contained in it that students must study.

The data analysis was done by describing the research results. Based on the observation instruments, it can be seen that the teacher's and students' activities were shown using frequency, percentage, and mean. Moreover, based on the observation results during the learning implementation, the teacher's activities related to giving the stimulus, leading the problem identification, and collecting the data combined with aspects of the scientific approach, namely observing, asking questions, exploring, associating, and presenting. Meanwhile, the students' learning results were given scores to get the learning competence made into grades.

\section{RESULTS AND DISCUSSION}

There are several points to assess creative thinking in this research, such as generating many ideas in various categories, having new ideas to solve the problem, and having the ability to solve the problem in detail (Kim 2006). Thus, it has shown in Table 1 below.

Table 1. Descriptive analysis result.

\begin{tabular}{lcc}
\hline Component & Pre-Test & Post-Test \\
\hline Maximum Score & 70 & 90 \\
Minimum Score & 20 & 50 \\
Average & 50.77 & 70.25 \\
$\mathrm{~N}$ & 25 & 25 \\
\hline
\end{tabular}

In this study, the students must learn with problem-solving activities, investigation, discovery, small-group work, learner-centered education, and using lecturer guidelines. True learning is learning that examines human problems in relation to the world (Bruner 1961). Discovery learning needs students to solve their own problems with the lecturer as a "trainer" for students. Students 
Table 2. Students creative thinking ability test.

\begin{tabular}{lcc}
\hline Component & Pre-test & Post-test \\
\hline Less creative & 15 & 0 \\
Quite creative & 5 & 10 \\
Creative & 5 & 10 \\
Highly Creative & 0 & 5 \\
N & 25 & 25 \\
\hline
\end{tabular}

are asked to "think" more and create rather than "quote" material (Schoenfeld 1980). Investigation is also important in this process because the lecturer can submit the lesson as material for students' thinking which encourages them to re-examine their previous thoughts. Students are free to express their thoughts (Simamora et al. 2019). Moreover, investigating is the process of discovering new things. In the discovery process, students must be involved in the discovery of various concepts and principles through problem-solving or the results of abstracting various cultural objects (Schoenfeld 1987).

However, this method is more effective using small groups compared to large groups. Schoenfeld (2013) said that ideas formed by individuals were often built and refined in collaboration with others. This implies that all cognitive, even high-level work in humans, starts from culture, and that means students should learn through interaction with adults and more capable peers. Teachers need to implement learning strategies that allow students to interact with their friends. In discovery learning, students are encouraged to learn on their own independently. Students are actively involved in discovering various concepts and principles through problem-solving or the results of the abstraction of various cultural objects. The teacher encourages and motivates students to gain experience by doing activities that allow students to discover mathematical concepts and principles for themselves. This learning arouses curiosity and fosters motivation in students to work until they find the answer. Students learn to solve problems independently with thinking skills because they must analyze and manipulate information (Simamora et al. 2019).

In the guided discovery learning model, the teacher acts as a guide. This guidance is needed to anticipate negative things such as cognitive overload, potential misunderstandings, and the teacher's difficulties in detecting problems and misunderstandings. Alfieri et al. (2011) stated that discovery learning without assistance has not benefited students, while feedback, examples of successful work, scaffolding, and teacher explanations such as reinforcement will benefit student learning achievement. Opportunities for constructive learning may not arise when students are left without help. The guided activity of the teacher has a scaffolding to help students. The activities given by the teacher require students to explain their ideas and ensure that these ideas are accurate by providing timely feedback from the teacher. The activities provided by the teacher provide examples of work on successful tasks. Table 2 presents the results of a student creative thinking ability test.

Participants' perceptions regarding the discovery learning method are more effective than ordinary learning methods or lectures. More than $90 \%$ of the participants stated that the discovery learning method is more effective than the usual method. Only 8 percent of participants disagreed. This is in line with Tran's (2014) research, which concluded that the discovery learning model is more effective than the traditional learning model. The difficulties in the discovery learning method are divided into five parts, namely: (i) understanding the material from related references; (ii) the interview process with experts; (iii) the interview process with the community; (iv) the process of presenting the results in the form of making videos and vlogs; (v) and the delivery of results. The most dominant difficulty faced by participants is presenting the results in the form of making videos and vlogs.

Making videos and vlogs is the hardest part. However, nearly one-third percent of participants stated that the presentation process in the form of video and vlog was the most interesting thing in the discovery learning process. Discovery learning is one method that is attractive and attracts 
participants. This is evidenced by 80 percent of the participants expressed their agreement/interest that if this method was applied, there were other courses.

\section{CONCLUSIONS}

Discovery learning can encourage students' creative thinking abilites in learning and teaching strategy subjects. There are huge differences in the pre- and post-test scores after discovery learning is implemented. This research implies that using discovery learning models is one solution to enhance students' creative thinking abilities. Moreover, this learning model is fit to be implemented in various fields of education. Meanwhile, if this model is applied to several exact courses, it should be combined with other models to increase students' understanding. This combination is done because students have different abilities and ways of absorbing knowledge. The combination is done, for example, by conducting intermittent lectures, testing individual understanding through quizzes to determine the effectiveness of learning outcomes and as learning evaluation materials.

\section{REFERENCES}

Alfieri, L., Brooks, P. J., Aldrich, N. J., \& Tenenbaum, H. R. 2011. Does discovery-based instruction enhance learning? Journal of Educational Psychology, 103(1), 1-18. https://doi.org/10.1037/a0021017

Amalia, Euis and M. Nur Rianto Al Arif. 2013. Kesesuaian Pembelajaran Ekonomi Islam di Perguruan Tinggi Dengan Kebutuhan SDM Pada Industri Keuangan Syariah di Indonesia. INFERENSI: Jurnal Penelitian Sosial Keagamaan Vol. 7 No. 1

Balım, A. G. 2009. The effects of discovery learning on students' success and inquiry learning skills. Eurasian Journal of Educational Research, 35(35), 1-20.

Bruner, J. S. 1961. The Act of Discovery. Harvard Educational Review, 3(1), 21-32.

Daryanto. 2013. Menyusun Modul: Bahan Ajar Untuk Persiapan Guru Dalam Mengajar. Yogyakarta: Gava Media.

Febrianto, Nur Fitroh and Wahyuningsari. 2017. CLC (Centered Learning Circular): Metode Revitalisasi Keilmuan Ekonomi Islam Untuk Kalangan Mahasiswa. al-Uqud: Journal of Islamic Economics, Volume 1 Nomor 1, Januari 2017. Hal 83-94

Indriyanti, Rita and Zuhdan Kun Prasetyo. 2018. Improving the Experiment Report Writing Skills of Fifth Graders Through the Discovery Learning Method. Jurnal Prima Edukasia, 6 (1), 2018, 104-102-110

Joyce, Bruce \& Weil. (2009). Models of teaching. New Jersey USA: Pearson Education, Inc, Publishing as Allyn\& Bacon.

Kamel, Abdelrahman. 2014. The Effect of Using Discovery Learning Strategy in Teaching Grammatical Rules to first year General Secondary Student on Developing Their Achievement and Metacognitive Skills. International Journal of Innovation and Scientific Research Vol. 5 No. 2 Jul. 2014, pp. 146-153.

Kim, K. H. 2006. Can We Trust Creativity Tests? A Review of the Torrance Tests of Creative Thinking (TTCT). Creativity Research Journal, 18(1), 3-14. https://doi.org/10.1207/s15326934crj1801_2

Lavine, Robert. 2005. Guided Discovery learning with Videotaped Case Presentation in Neur biology. JIAMSE. Vol. 16, 4-7.

Sari, V. N., \& Sukartiningsih, W. 2014. Penerapan model discovery learning sebagai upaya meningkatkan kemampuan menulis teks cerita petualangan siswa kelas IV sekolah dasar. Jurnal Penelitian Pendidikan Guru Sekolah Dasar, 2(2), 1-10.

Schoenfeld. A. H. 1980. Teaching Problem-Solving Skills. The American Mathematical Monthly, 87(10), 794-805. https://doi.org/10.2307/2320787.

Schoenfeld, A. H. 1987. Polya, Problem Solving, and Education. Mathematics Magazine, 60(5), 283-291.

Schoenfeld, A. H. 2013. Reflections on Problem Solving Theory and Practice. The Mathematics Enthusiast, $10(1,2), 9-32$.

Swaak, J., Jong, T,D. \& Joolingen, W.R. 2004. The effect of discovery learning and expository instruction on the acquisition of definitional and intuitive knowledge. Journal of Computer Assisted Learning. 20: 225234

Tran, Trung. 2014. Discovery learning with the Help of the Geogebra Dynamic Geometry Software. International Journal of Learning, Teaching and Educational Research (IJLTER). Vol. 7 (1), pp. 44-57.

Wenning. 2011. Levels of Inquiry Model of science teaching: Learning sequences to lesson plans. Journal of Phisics Theacher Education Online, 6(2), 17-20. 